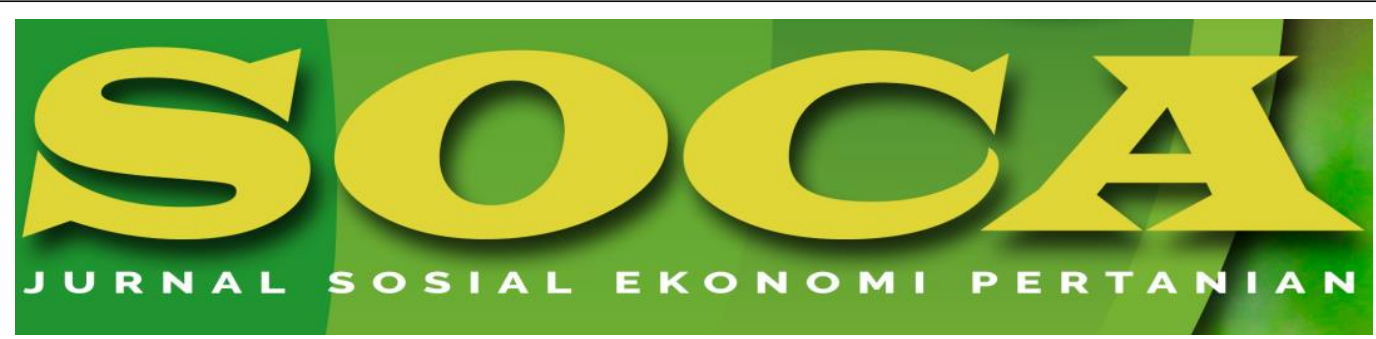

https://ojs.unud.ac.id/index.php/soca

\title{
Agricultural Commodity Supply Response
}

\author{
Gede Mekse Korri Arisena ${ }^{1}$ and Henita Fajar Oktavia ${ }^{2}$ \\ Agribusiness Department, Agricutural Faculty, Udayana University, Bali ${ }^{1}$ \\ Agribusiness Department, Agricultural Faculty, Borobudur University, Jakarta ${ }^{2}$ \\ E-mail:korriarisena@unud.ac.id ${ }^{1}$ and henitafajar@borobudur.ac.id ${ }^{2}$ \\ Mobile: $081944864138^{1}$ and $081217636790^{2}$
}

Submitted: 12 March 2020; Revised : 2 April 2020 ; Accepted: 12 April 2020

\section{Keywords: \\ supply response; agricultural commodity; government}

\begin{abstract}
Creating a farmer who able to actively respond to the agricultural commodity supply is a major challenge faced by the national government today. A dominant supply response to a certain factor would be easier to be identified by the stakeholder to arrange policies in improving the volume of agricultural commodity production. This study aimed to: 1) summarize the theories and study results about the supply demands, 2) analyze the factors that affected the supply response, and 3) examine the common problem-solving method used to analyze the supply response method. The secondary data was employed in this study by collecting relevant studies and theories. A review then conducted to address the study aims. Results showed that the farmer supply response to several factors was required to utilize the superior agricultural and horticulture (fresh fruit) commodity opportunities in competing on the world market. Vietnam, Thailand, and Latin America also strictly competing in exporting their commodity, but Indonesian healthy products were having a great chance to win this competition.
\end{abstract}

How to Cite (APA 6th Style):

Arisena, G. M. K., \& Oktavia, H. F. (2020). Agricultural Commodity Supply Response. SOCA: Jurnal Sosial Ekonomi Pertanian, 14(2), 362-380. https://doi.org/https://doi.org/10.24843/SOCA.2020.v14.i02.p15

\section{INTRODUCTION}

A set of policies to support the sustainability of the agricultural sector already implemented by the national government. Unfortunately, it couldn't deal comprehensively with the low level of agricultural commodity and the low marketing effort done by farmers. The most common problem found was the major role of the 
wholesaler in determining the commodity price, while the farmer was only able to accept the price without any further negotiation.

Sulistyo et al. (2017) stated that a high agricultural commodity demand would be a complex problem in the future. A small size of the agricultural cultivating land, a low amount of budget in improving agricultural productivity, and the damage on the irrigation infrastructure were creating a more rigorous agricultural situation. A high agricultural demand and low ability in meeting those demands would be threatening national stability. Tupamahu (2017) also stated that a demand for the product would increase accompanying the increased number of population and income.

Ferjani et al. (2013) explained that the increased price of the agricultural commodity was created some new perspectives about the food commodity supply and demand. In Swiss, the internal market, price, and the number of good produced was determined by the supply and demand. The supply response has become an important and crucial issue in the Swiss agricultural growth. A positive and significant price elasticity showed that the farmers were capable of interpreting the market opportunity and responded positively to the increase of price (Magrini et al., 2016). The supply response significantly affected by the marketing cost provided by the farmer.

A study done by McKay et al. (1998) showed that the majority of the farmers were not responsive to the government policies that provided a bias effect on their agricultural commodity. They stated the econometric technique used was not appropriate. They also found that the agricultural response was quite high (supporting the World Bank data, 1994). Their finding was also parallel with the result from a qualitative study about the economic reformation. Results from their study showed that the agricultural response potential to the agricultural commodity price and marketing were quite significant.

According to the data in the community, the farmer, worker, and the parties in an agribusiness industry would passionately work on their business if their agricultural commodity's price increasing. This price moved the dynamic of agribusiness in a village, therefore the price played an important role in the center of village economic production. The local market protection also assured the agricultural commodity's price. This study aimed to: 1) summarize the theories and study results about the supply demands, 2) analyze the factors that affected the supply response, and 3) examine the common problem-solving method used to analyze the supply response method.

\section{RESEARCH METHODS}

Secondary data was employed in this study. Secondary data is fixed data, collected by other researchers or organizations (Sulaiman et al., 2013). The method used was the literature study that could be defined as a collection data method done by summarizing the relevant topics or theories cited from books or research articles to address the study aim (Juliandi et al., 2014). This study didn't simply cite the theories or results, but also analyzing the agricultural commodity supply responses problem. The literature used was including information about the supply response, study method, theory, application, and all things that concentrated on the supply responses. We then reviewed those works of literature to address the study aims. 


\section{RESULTS AND DISCUSSION \\ Supply Responses}

Heriyanto et al. (2013) was published a study article entitled "Supply Response Dynamic on Peanut Commodity in Indonesia" which explained about the peanut supply response in Indonesia. They didn't explain the definition of supply specifically. The supply response depended on the several factors that affected the commodity volume production. A dominant supply response to a certain factor would be easier to be identified by the stakeholder to arrange policies in improving the peanut volume production. Results showed that the peanut commodity's price was positively correlated with the supply, but the peanut and other agricultural commodity volume production at the previous year was negatively correlated with the supply. While the price elasticity of the peanut supply on the long and the shortterm period was inelastic. The cross-price supply elasticity showed that the characteristic of the peanut commodity was able to compete with other agricultural commodities. This study then concluded that the improvement of the farmer supply response accompanied by the production infrastructure, production system, distribution and market insurance system, and technology dissemination improvement is required to increase the peanut commodity volume production.

Sulistyo et al. (2017) in their study entitled "Indonesia Rice Paddy Supply Response Analysis" also didn't explain the definition of supply clearly. Results showed that the supply response elasticity value in a short time and in the long term was $0.888,0.153$ respectively. This result indicated that the farmer was responsive to the price change. These elasticities were ranged on the inelastic value, which means that the supply percentage change was lower than the price. The supply would change as much as $0.088 \%$ on the short term range and $0.153 \%$ on the long term range if the price change per one percent of the grain price.

Hernawaty et al. (2016) also didn't explain the definition of supply in their study entitled "Rice Paddy Supply Response in South Borneo". However, they explained the definition of rice paddy supply as the total of grain or rice offered by the farmer to the buyer using a certain amount of price. This study finally concluded that: 1) the rice paddy cultivating area size was influenced by the rice paddy and fertilizer's prize at the previous year; 2) the rice paddy productivity was influenced by the rice paddy and the productivity at the previous year; 3) the rice paddy supply response on the rice paddy cultivating area size and productivity was quite good, the independent variables were ably describing the rice paddy cultivating area size and productivity with the total of percentage $96.1 \%$ and $96.4 \%$ respectively, 4) rice paddy supply response elasticity on the short and long-term period was inelastic; 5) the study population couldn't appropriately responded on the price change, the elasticity showed that the farmer's response to the price change was really low.

Tupamahu (2017) on his study about the "Peanut Supply Response in Indonesia" didn't describe the definition of supply. The result from this study showed that there were some factors affected the peanut supply response, they are peanut commodity price at the previous year, the rice paddy commodity price at the previous year, the bean commodity price at the price year, and the peanut commodity volume production at the year of t. The supply response elasticity in the short-term and longterm periods was elastic. While the cross-price elasticity according to the rice paddy and bean price at the previous year was inelastic.

Firdaus (2014) was conducted a study to know the bean commodity supply response in Indonesia. They also didn't explain the definition of supply. This study concluded that: 1 ). The price lag between the bean and dummy price was affected by the bean cultivating area size, 2). The productivity lad and the bean price lag was affected the real bean productivity, while the bean cultivating area didn't, and 3) the 
supply response was majorly affected by the productivity response than the areal response.

Heriyanto et al. (2011) in the study entitled "Cassava Commodity Supply Response in Indonesia" was explaining the definition of supply based on Anwar (1986). This study also described the effectivity of some efforts in shifting the supply function which was ranged between two parameters: 1) supply response elasticity to the areal; and 2) supply response elasticity to the productivity. The areal response was related to the effectivity of extensification and the productivity responses were related to the effectivity of intensification. Results showed that the cassava supply response was affected by the cassava and peanut commodity price at the previous years and peanut commodity price this year. According to its price elasticity, the cassava commodity price categorized as inelastic, but the cross-price elasticity with the soil was a competitive product produce by the cassava commodity, while the bean price was a joint product. This study suggested improving the cassava commodity volume production in order to cancel the increase in cassava commodity volume production policies.

Edison et al. (2018) in the study entitled "Corn Commodity Supply Response Analysis in Muaro Jambi Regency" explained the definition of supply based on the definition stated by Houck and Ryan (2003). The response supply on the agricultural commodity analysis showed that the government program was majorly impacted the agribusiness that tried to control its volume production. Therefore, the integration of the agribusiness program on the supply response model was studied. Results showed that the corn commodity supply response was affected by many factors, they are internal and external factors. The rice paddy's price, input, and the season was the most relevant factors affected the supply response. The corn commodity supply response would increase if the rice paddy commodity price increase. The corn commodity would be decreased if the input variables also decrease. The corn cultivating area size also significantly impacted the corn volume production. The season also played an important role on the corn commodity production, the corn production would be significantly increased during the rainy season because the availability of water was an important factor for the growth of the corn plant. The analysis showed that the farmer on the dryland was able to utilize the input factor effectively. The output supply response was a response to the corn commodity volume production. On the input demand aspect, the utilization of the worker was relatively sensitive. The production elasticity was completing the part from the database needed in evaluating the implication of input alternatives from the corn stock and input demand policies.

Oktavia (2019) in the study entitled "Corn Commodity Supply Response in Malang Regency, East Java" also didn't explain the supply response, but they cited a study done by Mahmudah (2014) that stated supply was closely correlated with the cultivating area size and the productivity. Therefore, a supply approach must be including those factors. Result showed that from the four independent variables studied (corn commodity price one year ago, corn cultivating area size one year ago, cultivating area size two years ago, and rice paddy's price at the current year) and predicting the supply response based on the cultivating area size, only one variable (corn commodity price one year ago) significantly affected the supply response with the value of 0.063 . From other five independent variables studied (corn commodity price one year ago, productivity two years ago, the urea fertilizer price at the current year, and sugar cane cultivating area at the current year) and predicting the supply response based on the corn commodity productivity, no variable significantly affected the supply response. The elasticity value for the productivity response didn't calculate in this study due to the corn commodity price one year ago was not significantly affected the corn productivity. This result indicated that the corn commodity supply response in Malang Regency only analyzed through the cultivating 
area elasticity value. The short-term supply response elasticity was more than one but the values were negative which showed that the fluctuated price interfered with the farmer's decision in deciding to use a larger cultivating area. According to the long-term elasticity value (1-2.72) the corn commodity price should be increased if the cultivating technique is getting repaired and the government able to repair the situation by providing adequate agricultural aid. Therefore, the farmer could extend their cultivating period and increasing the supply response through the extention of the cultivating area.

Ayinde et al. (2017) in the study entitled "Analysis of Supply Response and Price Risk on Rice Production in Nigeria" also didn't explain the definition of supply but directly elaborated on the definition of supply response. The analysis showed that the producer was more responsive to the price factor, non-price factor, price risk factor, and the exchange rate. Therefore, the price risk effect was important in increasing the producer response on the supply by bridging the production process gap.

Khan et al. (2019) was written a study entitled "Supply Response of Rice Using Times Series Data: Lessons from Khyber Pakhtunkhwa Province, Pakistan". This study also didn't explain about the supply definition, but more concentrated on the supply elasticity and the supply response model. The result showed a significant result $(\mathrm{p}<0.05)$. The long-term and short-term elasticity respectively was 0.597 and 1.481 for production, 0.037 , and 0.091 for the price, and -0.066 and -0.163 for the rival plant (corn). Inelastic correlation was found on price lag and the rival plant, but the production lag showed an elastic correlation in the long-term elasticity. This study suggested that the price must be maintained stably to provide the farmer the chance in extending their cultivating area for certain types of plants. Modern technological devices must be provided in a normal cost and extentions must be arranged to improve the farmer ability in adopting novel technology and increasing their productivity.

Cahyono, et.al. (2020) in the study entitled "Analysis of Cocoa Supply Response in Indonesia" also didn't explain the definition of supply. The result showed that the factors affected the cocoa supply responses based on the number of plants were the cocoa price three years ago, the amount of interest at three years ago, and the number of cocoa produced in the previous years. These factors positively impacted the supply response, while the CPO was negatively impacted on the supply response. Factors affected the supply response based on the productivity level was the cocoa commodity price at the current year (positive impact) and the urea fertilizer price (negative impact). The short-term and the long-term supply elasticity respectively was 0.189 and 0.347 (inelastic). To increase the supply response the government needs to give an input subsidy to the farmer and maintaining the plantation preservation.

Prasada, et.al (2018) in a study entitled "Supply Response of Paddy in East Java: Policy Implications to Increase Rice Production" didn't explain about the definition of supply. The result showed that the adjustment rate on the short-term supply response was $2.79 \%$ and getting better in the next period. On the short-term elasticity, all variables were not responsive to the rice paddy supply, but in the longterm period the irrigation area was very responsive to the rice paddy supply in East Java with a total value of elasticity of 1.79 . The rice paddy supply response could be improved by increasing the real grain price, irrigation land-area, and the cultivating area size.

Bachtiar et.al (2014) in a study entitled "Supply Response and Corn Price Volatility in Indonesia" also didn't explain about the definition of supply. The result showed that the price volatility was an important risk factor. They concluded that 1) the price on the producer level significantly affected the corn forecast price and the estimation from the price equation expected to show the constant price volatility, 2) 
the fertilizer price, the distributor corn price, the rice paddy price on the producer level, and the variance price expected from the corn producer affected the corn supply response, and 3) the most appropriate model that describing the expected price equation system and supply response equation was EGARCH (1.1).

Nugroho, et.al (2015) in a study entitled "Salacca zalacca Supply Response in Salatiga City" didn't explain about the definition of the supply. Result obtained a supply response function model which was showed as Ln Qt $=-1.960+0.809 \mathrm{Ln} \mathrm{Pt}$ $1+0.282$ Ln Qt- $1-0.560$ Ln Wt+ 0.660 Ln At + 0.395 Ln Qrt-1 - 0.497 LnPZt + e. The determination coefficient (R2) was 0.941. Based on the F test, the value was 0.000 that indicated a significant meaning in the level of $99 \%$. While the t-test result showed that the volume production at the previous year, the price at the previous year, the number of plants that actively contributed to the production volume during the cultivating years, the rambutan volume production at the previous year, and the rainfall mean at the cultivating year affected the supply response. The supply response elasticity in Salatiga City $(\mathrm{Ep}<1)$ was positive inelastic and the value of the mean of the rainfall was negative inelastic $(\mathrm{Ep}>-1)$.

Magfiroh et al. (2018) in a study entitled "Corn Commodity Supply Response in Indonesia" explained the supply definition based on the Tomek W and Robinson KL (1990) as a functional relation that showed the amount of commodity offered in certain place and time on various price level, while the other factors were still constant. Results showed that the farmer's supply response affected by the bean commodity price, worker's salary, seed price, urea fertilizer's price, fodder's price, and the import corn commodity price. Result also showed that the farmer was responsive to the corn commodity price change. Therefore, price stability was required to be used in supporting the balance condition of corn commodity. This study also suggested an input subsidy and extension of the cultivating area policies to improve the corn supply.

Based on the result of those studies, we concluded that supply response was important information needed in analyzing the supply responses. In the agricultural field, supply response provided adequate data to understand the farmer's response to their agribusiness decision. These supply responses could be represented as a commodity elasticity in a long or short term period and the most important parameter was the price, production, productivity, and cultivating area size.

\section{Factors Affecting Supply}

A study done by Hermawan et al. (2010) showed that some factors affecting the amount of cotton fiber supply in Indonesia: the total production volume, export, and cotton fiber import. The cotton fiber production volume was affected by the size of the cultivating area and the cotton fiber production volume in the previous year. The total cotton fiber export volume was affected by the cotton fiber price in the world level, the Rp/ US\$ exchange rate, and the previous export volume. While the fiber import volume was affected by the Indonesia population, time trend, and the cotton fiber import volume on the previous year.

On the production aspect, the result from the study done by Hermawan et al. (2010) could be linked with the result of the study done by Sugiarto et al. (2005). Production could be defined as the process of turning the input to output. The input consisted of the production factors, such as capital, labor, soil, natural resources, and human skill. These inputs would be transformed into a product or service with certain added-value. The quality and quantity of the output would depend on the input used during the production process. The price of each input aspect would also affect the output supply. Simanjuntak et al. (2017) was also defining the production process as the utilization of the resources by turning a commodity into another commodity with a higher value. A good production process would produce good 
quality output, while poor production processes would also produce poor quality output.

A commodity supply also affected by their import volume (Hermawan et al., 2010). A study done by Abidin (2015) showed that Indonesia faced a major challenge in achieving their national food stability. The higher national population resulted in a higher food demand. The total import value in the period of 2000-2013 was reached US\$ $6,294,293,000$ with a total volume of $18,080,271$ tons. The highest imported rice volume that happened in 2000 was reached 4,751,398 tons with a total of US\$ $1,327,459,000$, while the lowest imported volume happened in 2006 that reached $189,616.6$ tons with a total of US\$ 51,499,000. Vietnam, Thailand, China, India, Pakistan, and the USA were the main rice exporter in Indonesia. Fitri (2018) also stated that Indonesia has a complex problem in providing national rice supply. The weak production and low rice supply were majorly contributed to this complex problem. The rice production in Indonesia was constantly increasing, the level of consumption was also decreasing, but unfortunately these conditions didn't affect the ability in meeting the national rice supply.

The export volume is also affected a product supply (Hermawan et al., 2010). Export could be defined as the activity of selling a product made inside the country to be sold or used in other countries (Griffin \& Pustay, 2015). Export is important in increasing the national profit and income. Export is also able to extend the marketing line of certain commodities or services which finally could improving the industries productivity. The profit from the export activities would be managed by the country to maintain the national economic growth. Result form a study done by Zakariya et al. (2016) explained the IDR exchange rate on the US Dollar was negatively correlated with the export volume of the Indonesian cocoa beans. The increase of one IDR exchange rate on the dollar US exchange rate would decrease 0.611 the Indonesian cocoa beans export volume. This was indicated that a decrease of one IDR exchange rate on the US dollar would increase 0.611 the cocoa beans export volume.

The Indonesian agricultural commodities were highly potential to be participated on the world export market. South American was known by its popularity as the main staple food exporter in the world, but actually if reviewed from the commodity quality, the Indonesian agricultural commodity quality was better than their agricultural commodity. Indonesia is also able in providing healthy horticultural commodities such as tropical fruits better than some countries (Vietnam, Thailand, and Latin America). The Indonesian national government is already conducting an effort to assure the food commodity marketing line by providing warehouses in some production centers.

\section{The Agricultural Commodity Supply Response Problem-Solving Analysis Method}

Heriyanto et al. (2013) was published a study article entitled "Supply Response Dynamic on Peanut Commodity in Indonesia" which explained about the peanut supply response in Indonesia. They used a Nerlove equation model which combining the Partial Adjustment Model and Adaptive Expectation Model (stationary data) as formulated below:

$A_{t}^{*}=\alpha_{0}+\alpha_{a} P_{t}^{*}+\alpha_{2} Z_{t}+u_{t}$

$A_{t}=A_{t-1}=\gamma\left(A^{*}-A_{t-1}\right)$

$P_{t}^{*}=\beta P_{t=1}+(1-\beta) P_{t=1}^{*}$

Where: A_t: the peanut cultivating area at the year of $-t ; A_{-} t^{\wedge *}:$ the desirable peanut cultivating area at the year of $-\mathrm{t}, \mathrm{P}_{-} \mathrm{t}$ : the actual peanut commodity price at the year of $-\mathrm{t} ; \mathrm{P}_{-} \mathrm{t}^{\wedge *}$ : the expectation of peanut commodity price at the year of $-\mathrm{t} ; \mathrm{Z}_{-} \mathrm{t}$ : other independent variable that affected the peanut commodity supply at at the year of $-t$ and $\beta$ : expectation coefficient; $\gamma$ : adjustment coefficient. 
The short-term elasticity formulated as: $\epsilon_{s r}=b_{1} \frac{\overline{P_{t}}}{\overline{A_{t}}} ;$

The long-term elasticity formulated as : $\epsilon_{l r}=\frac{b_{1}}{1-b_{2}-b_{3}} * \frac{\overline{P_{t}}}{\overline{A_{t}}}$.

Sulistyo et al. (2017) in their study entitled "Indonesia Rice Paddy Supply Response Analysis" was using the Nerlove Response Model. This model is a single equation model build by the combination between the size of the harvesting area and rice paddy productivity model. The rice paddy supply model was predicted by these models. The Nerlove Response Model formulated as below (Anindita, 2008):

$A_{t}^{*}=\alpha_{0}+\alpha_{1} P_{t}^{*}+\alpha_{2} Z_{t}+u_{t}$

$P_{t}^{*}=P_{t-1}^{*}+\beta\left(P_{t-1}-P_{t-1}^{*}\right)$

$A_{t}=A_{t-1}+\gamma\left(A_{t}^{*}-A_{t-1}\right)$

Where: $A_{t}$ : the cultivating area at the year of $-\mathrm{t} ; A_{t}^{*}$ : the desirable cultivating area at the year of $-\mathrm{t}, P_{t}$ : the actual commodity price at the year of $-\mathrm{t} ; ; P_{t}^{*}$ : the expectation of commodity price at the year of $-\mathrm{t} ; Z_{t}$ : other independent variable that affected the commodity supply at at the year of $-\mathrm{t}$ and $\beta$ : expectation coefficient; $\gamma$ : adjustment coefficient.

This formula used to determine the supply response model and its short/long-term elasticity. The study result was written in the form of areal response and productivity response. The elasticity supply response could be predicted by: $E_{(Q)}=E_{(A P)}+E_{(Y P)}$.

Hernawaty P et al. (2016) on the study entitled "Rice Paddy Supply Response in South Borneo" was using the Nerlove Model as follow:

$$
L n A_{t}=\operatorname{Ln} a_{0}+a_{1} \operatorname{Ln} P_{t-1}+a_{2} \operatorname{Ln} A_{t-1}+a_{3} \operatorname{Ln} Z_{t}+e_{t}
$$

Where: : $\operatorname{Ln} A_{t}$ : rice paddy cultivating area size (1997-2015); $L n a_{0}$ : constanta; $a_{1}, a_{2}, a_{3}$ : regression coefficient; LnP_(t-1): rice paddy's price on the farmer level $(\mathrm{Rp} / \mathrm{Kg})$; $L n P_{t-1}$ : rice paddy cultivating area size at the previous year (1996-2014); $\operatorname{LnZ} Z_{t}$ : fertilizer's price $(\mathrm{Rp} / \mathrm{Kg}) ; e_{t}$ : other disruption variables.

To know the productivity response, the researcher was applied this formula:

$$
\operatorname{Ln} Y_{t}=\operatorname{Ln} b_{0}+b_{1} \operatorname{Ln} P_{t-1}+b_{2} \operatorname{Ln} Y_{t-1}+b_{3} \operatorname{Ln} Z_{t}+e_{t}
$$

The effect of the rice paddy supply elasticity value (response) on the rice paddy's price on the short-term and long-term period in South Borneo was evaluated using the following formula and criteria:

1) The supply elasticity on the cultivating area size equation:

a. short-term supply elasticity (Esr) $=a_{1}$;

b. long-term supply elasticity $($ Elr $)=\frac{a_{1}}{1-a_{2}}$

Where: $a_{1}$ : price regression coefficient; $a_{2}$ : cultivating area size regression

2) The supply elasticity on the productivity equation:

a. short-term supply elasticity $(\mathrm{Esr})=b_{1}$

b. long-term supply elasticity $(\mathrm{Elr})=\frac{b_{1}}{1-b_{2}}$

Where: $b_{1}$ : price regression coefficient; $b_{2}$ : productivity regression coefficient

Tupamahu (2017) on his study entitled "Peanut Supply Response in Indonesia" was employing a dynamic Nerlove model. This model was employing the expectation price, land adjustment, and other variables as the output. Nerlove Model was a combination between the Partial Adjustment Model and Adapative Expectation Model.

$A_{t}^{*}=\alpha_{0}+\alpha_{1} P_{t}^{*}+\alpha_{2} Z_{t}+u_{t}$
$A_{t}-A_{t-1}=\gamma\left(A_{t}^{*}-A_{t-1}\right)$
$P_{t}^{*}=\beta P_{t-1}+(1-\beta) P_{t-1}^{*}$

Where: A_t: the peanut cultivating area at the year of -t; $A_{t}^{*}$ :the desirable peanut cultivating area at the year of $-\mathrm{t}, P_{t}$ : the actual peanut commodity price at the year of - $\mathrm{t} ; P_{t}^{*}$ :the expectation of peanut commodity price at the year of $-\mathrm{t} ; Z_{t}$ : other independent variable that affected the peanut commodity supply at at the year of $-t$ 
and $\beta$ : expectation coefficient; $\gamma$ : adjustment coefficient. The short-term elasticity was formulated as: $\varepsilon_{s r}=\frac{\overline{P_{t}}}{\overline{A_{t}}}$; while the long-term elasticity eas formulated as: $\varepsilon_{l r}=\frac{b_{1}}{1-b_{2}-b_{3}}$ $* \frac{\overline{P_{t}}}{\overline{A_{t}}}$.

This OLS (Ordinary Least Square) method was used to predict the model of supply. The strength of this method (Koutsoyiannis, 1977) were: 1). OLS was processed the parameter forecaster well; 2). The calculation was relatively simple and didn't need much data; 3). OLS is a common method employed in understanding various economic models; 4). The mechanism of the OLS method was easily understood; 5). OLS is an important component among other economic methods.

Firdaus (2014) in the study entitled "Bean Supply Response in Indonesia" was using a partial adjustment model which commonly used in supply response study. This model was created by combining two indirect model approaches: areal and productivity response, similar to the Nerlove Model that employing a factual approach. This model was providing a more efficient approach in estimating the parameters than the direct approach model. According to the areal and productivity response, the supply response could be formulated using an equation with a decomposition as follow: $E_{(Q, P)}=E_{(Y, P)}+E_{(A, P)}\left(1+E_{(Y+A)}\right)$.

The supply response predicted indirectly by predicting the productivity to price elasticity (response) or $E_{(Y, P)}$, cultivating area size to price elasticity (response) or $E_{(A, P)}$, and productivity to cultivating area size elasticity (response) $E_{(Y+A)}$.

Based on the explanation, the bean cultivating area was formulated as the function of the bean quantity at the previous year, the bean cultivating area at the previous year, and the basic price policies (dummy variable). The farmer was assumed to be able in adjusting the bean cultivating area with the price in the previous period. The productivity response was obtained by the same method. The bean productivity was the function from the bean nominal price and bean cultivating area lag.

Heriyanto et al. (2011) in the study entitled "Cassava Commodity Supply Response in Indonesia" were analyzing the factors affected the cassava commodity supply response. The hypothesis used in formulating this supply response model were: 1). The price expectation accepted by farmers in the following period as a proportion of the error in predicting the prices in the past period; 2). The farmers were having static expectations in planning the commodity production according to the price during the harvesting period (Nerlove, 1956 dan 1958; Berhman, 1968; Yotopoulus, 1976). Mathematically, it formulated as follow (the 10th derivate from the initial adaptive expectation formula (Cagan, 1954):

$$
H_{t}^{e}-H_{t-1}^{e}=\beta\left(H_{t-1}-H_{t-1}^{e}\right) ; 0<\beta<1
$$

$H_{t}^{e}$ : the price expectation on the year t; $H_{t-1}^{e}$ : the price expectation on the year $\mathrm{t}-1$; $H_{t-1}$ : the actual price at the year $\mathrm{t} ; \beta$ : expectation coefficient.

This formula was developed and derivated into some formulas (16a, 16b and 17) which was also the short-term elasticity formula, long-term elasticity formula, and specific model from the cassava commodity supply response in the study.

Short-term elasticity $\quad: E_{s r}=\alpha_{1} \gamma\left(\frac{H_{t}}{Z_{t}}\right)$

Long-term elasticity

Supply Response Specific Mode :

$$
: E_{l r}=\gamma\left(\frac{H_{t}}{z_{t}}\right)
$$

$$
Z_{t}=\beta_{0}+\beta_{1} H_{t, t-1}+\beta_{2} H_{2, t-1}+\beta_{3} H_{3, t-1}+\beta_{4} H_{4, t-1}+\beta_{5} H_{5, t-1}+\alpha_{1} \operatorname{Prod}_{t-1}+V_{t}
$$

The equation of 17 was analysed using a least squared method. The asumptions applied on the analysis were (Kmenta, 1971; Intriligator, 1980; Gujarati, 1988): 1). v_t normally distributed; 2). $\left.\left.\mathrm{E}\left(v_{t}\right)=0 ; 3\right) . \mathrm{E}\left(v_{t}^{2}\right)=\delta^{2} ; 4\right) . \mathrm{E}\left(v_{i} v_{j}\right)=0$ for $\mathrm{i} \neq \mathrm{j}$; and $5)$. No colinerityon the independent variables. 
Edison et al. (2018) was studied the corn commodity supply response analysis in Muaro Jambi Regency. They used an empiric meta-profit function model to analyze the supply response. The translog function analysis variable was having the same function as the production function used, but expressed in the form of basis/hectare. The empiric model of this profit function could be written in the form of an algorithm from the Cobb-Douglas function. The normalization of the profit function used to determine the corn commodity supply response which expressed as:

$$
\mathrm{Y} Y=a \pi X_{i}^{b i} \pi Z_{j}^{c j}
$$

The limited normalization the profit function equation was derivated from the production function (1), as explained by (Lau, 1979):

Where: $\pi^{*}$ : the normalization of the limited profit (IDR), $\mathrm{P}_{1}$ : the normalization of the fertilizer used (IDR); $\mathrm{P}_{2}$ : the normalization of the pesticide (IDR) $\mathrm{P}_{3}$ : maintenance cost (IDR); $\mathrm{P}_{4}$ : salary $(\mathrm{Rp}) ; \mathrm{Z}_{1}$ : land area size (Ha); $\mathrm{Z}_{2}$ : the capital used (IDR); U: error; $\mathrm{a}, \beta$, $\pi, \Sigma$ : estimation parameter. The supply response estimation was examine by twostage method. The value of the chi-square used in examining the study hypothesis. The parameter estimation from the supply response function obtained from those steps was constant (Judge, 2004). The estimation parameter didn't measure the effect of a unit variable in changing the level of profit from commodity volume production directly. To obtained the optimal level of input variable, the ShephardHotelling was combined with the Cobb-Douglas:

$$
X_{i}^{*}=\frac{-\delta \pi^{*}}{\delta P_{i}}
$$

The equation of $\mathrm{E}\left[U\left(\pi^{*}\right)\right]=E\left[v^{*}(P, C, T, \theta, \varepsilon)\right]$ re-arranged and estimated empirically as: $\frac{\left(X_{i}^{*} P_{i}\right)}{\pi^{*}}=\beta_{I}+V_{t}$.

Where:

$X_{i}^{*}$ : input variable quantity $X_{i}^{*}$ : error

The production function was assumed in a Cobb-Douglas form, the simultaneous equation solution was $\frac{\left(X_{i}^{*} P_{i}\right)}{\pi^{*}}=\beta_{I}+V_{t}$. and the profit function $Y=$ $a \pi X_{i}^{b i} \pi Z_{j}^{c j}+\mathrm{U}$ completing the demand factor elasticity estimation, Zellner's seemingly unrelated regretion method, completing the parameter efficiency of a, $\beta, \pi, \Sigma$ (Judge, 2004). This model estimated by the Ordinary Least Squares in estimating the coeficient, , $R^{2}$, the value of-t, and Durbin Watson value.

Oktavia (2019) in a study entitled "Corn (Zea mays) Commodity Supply Response in Malang Regency, East Java" using a Partial Nerlove Adjustment Model (Nerlove Adjustment Model). The model used was cited from Anindita (2008) who wrote about the Nerlove Supply Model as the combination between the Partial Adjustment Model and Adaptive Expectation Model. Partial Adjustment Model is a model that explained the supply change due to the technical hindrances, adjustment cost, or a habit that interfere with the supply changes into the market balance indirectly. The Adaptive Expectation Model used because of the variable expectation resulted in a delay in the production process. The corn commodity cultivating area model was formulated as follow:

$$
A j=\alpha_{0}+\alpha_{1} H J_{1}+\alpha_{2} L A_{1}+\alpha_{3} L A_{2}+\alpha_{4} H P+e
$$

Where $\mathrm{Aj}$ : corn cultivating area size; HJ1 : the corn price one year ago (IDR/kw); LA1: corn cultivating area size one year ago (Ha); LA2 : corn cultivating area size two years ago (Ha); HP: the rice paddy price at the current year (IDR/kw).

In the Corn Commodity Productivity

$$
\mathrm{Yj}=\beta 0+\beta 1 \mathrm{HJ} 1+\beta 2 \mathrm{Y} 1+\beta 3 \mathrm{Y} 2+\beta 4 \mathrm{HPU}+\beta 5 \mathrm{LA}+\mathrm{et}
$$

Where $\mathrm{Yj}$ : corn commodity productivity $\mathrm{HJ}_{1}$ : corn commodity price one year ago $(\mathrm{Rp} / \mathrm{kw}) ; \mathrm{Y}_{1}$ : corn commodity productivity one year ago $(\mathrm{Ku} / \mathrm{ha}) ; \mathrm{Y}_{2}$ : corn 
commodity productivity two years ago (Ku/ha); HPU: urea fertilizer price at the current year $(\mathrm{Rp} / \mathrm{Ku})$; LA : sugar cane cultivating area size (Ha)

Supply Elasticity

$\mathrm{Esr}=\frac{d A}{d_{X n}} \frac{X_{n}}{A}=b_{n} \frac{X_{n}}{-A^{-}}$
$\mathrm{Elr}=\frac{E_{S r}}{\delta}=\frac{E_{S r}}{\left(1-b_{n-1}\right)}$

Where Esr : price elasticity for the short-term demand; Elr : price elasticity for the long-term demand; $\mathrm{Xn}$ : representing the independent variable $\mathrm{n}$; bn : coefficient from the Xn; $\delta: 1-b n-1=$ adjustment coefficient.

Ayinde et al. (2017) in the study entitled "Analysis of Supply Response and Price Risk on Rice Production in Nigeria" was using the equilibrium output supply function, co-integration and model vector autoregressive distributed lag function. But they didn't explain the vector autoregressive distributed lag model specifically on the study. On the supply response model, the supply response input and output function was following the Nerlove (1958) and Quiggin (1991) and would be used for determining the rice paddy production analysis pattern which formulated as folows:

$$
\mathrm{Qt}=\mathrm{F} \text { (HAt, Pt, Mt, RFt, et) }
$$

Where: $\mathrm{Qt}=$ rice paddy output on the year of $\mathrm{t} ; \mathrm{HA}=$ the cultivating area size at the year of $\mathrm{t} ; \mathrm{Pt}=$ producer price/ton; $\mathrm{Mt}=$ the import volume production on the year of $\mathrm{t}$; $\mathrm{RFt}=$ season variable (rain) on one milimeter; et $=$ error. The output supply response was adopting the multiple algorithm which represented as the formulation as follow:

$$
\ln Q t=ß 0+ß 1 \ln H A 1+ß 3 \ln M t+ß 4 \ln R F+U t
$$

All variables were arranged in natural algorithms. The vector autoregression model used was adapted from Johansen $(1988,1995)$ in analyzing the rice paddy supply responses in Nigeria. This model also applied to predict the rice paddy supply response level to the risk of the price change. The model variable also included on the co-integration model.

$$
\text { At }=a 1 P t+a 2 V+a 3 K+a 4 R
$$

Where $\mathrm{A}=$ rice paddy output; $\mathrm{P}=$ price; $\mathrm{V}=$ price change; $\mathrm{K}=$ output change; $\mathrm{R}$ $=$ real exchange rate.

Khan et al. (2019) in the study entitled "Supply Response of Rice Using Times Series Data: Lessons from Khyber Pakhtunkhwa Province, Pakistan" was using an Augmented Dickey-Fuller test to normalize the zero lag and one lag. The data got the stationary state on the one lag condition. The vector autoregression was a model used in the analysis process that done by taking production log as the dependent variable, production lag-log, rice paddy lag-log, and the rival plant price lag-log as the independent variable. The formula was derivated using the Nerlove Model and also applied to the Koyck transformation which expressed as follow:

1. short-term elasticity $: \epsilon_{s}=\frac{\delta Q_{t}^{S}}{\delta P_{t-1}} \cdot \frac{P_{t-1}}{Q_{t}}=\pi_{1} \cdot \frac{\bar{P}_{t-1}}{\bar{Q}_{t}}$

2. long-term elasticity $: \epsilon_{L}=\frac{\epsilon_{s}}{\gamma}$ where $\gamma=1-\pi_{2}$

The short-term supply elasticity was a supply response to the price change in the initial period reaction. A high change was expected on the short-term period, while the long-term elasticity showed the price change in the longer-term period.

For the empiric model $\ln Q_{t}^{S}=\lambda_{0}+\lambda_{1} \ln P_{t-1}+\lambda_{2} Q_{t-1}^{S}+\lambda_{3} \ln P_{m(t-1)}+e_{t}$

Where: $Q_{t}^{s}$ the number of supply; $\mathrm{P}_{\mathrm{t}-1}$ price at the previous year; $Q_{t-1}^{s}$ : supply number lag; $P_{m(t-1)}$ : rival plant lag and $e_{t}$ : error.

Wahyu et al. (2020) in the study entitled "Analysis of Cocoa Supply Response in Indonesia" was using co-interaction and error correction model method. The data used also going through stationery process. The model used in this study was adopted from Dellal et al. (2003) which was studied about the supply response on 
the Turkish apricot. Dellal et al. (2003) also adapted this model from the French et al. (1971) which studied the supply response of the annual plant. These were some model apllied in the study:

1. The Total of Cocoa Plant (TM)

$\operatorname{lnJTMt}=\mathrm{f}(\operatorname{lnPkPt}-3, \ln$ PCPOt-3, $\operatorname{lnSBIt}-3, \operatorname{lnJTMt}-1)$

2. Cocoa Productivity Level

$\ln Y \mathrm{t}=\mathrm{f}(\ln \mathrm{PkPt}, \ln P P U t, \operatorname{lnYt}-1)$

Where: $\ln J T M t=$ the number of cocoa plant at the year of $t$ (year); $1 n P k P t-3=$ the cocoa price on the at the year t-3 (IDR/Kg); lnPCPOt-3= The CPO domestic price at the year of t-3 (IDR/Kg); lnSBIt-3 = the interest rate at the year of $\mathrm{t}-3$ (percent); $\ln \mathrm{JTMt}-1=$ the number of cocoa plant produced at the year of $\mathrm{t}-1$ (tree); $\operatorname{lnYt}=$ the cocoa plant productivity level at the year of $\mathrm{t}(\mathrm{Kg} / \mathrm{tree}) ; \mathrm{lnPkPt}=$ the cocoa price on the producer level in the year of $\mathrm{t}(\mathrm{IDR} / \mathrm{kg}) ; \ln \mathrm{lPUt}=$ the urea fertilizer price at the year of $\mathrm{t}-1$ (IDR/Kg); lnYt-1 = the cocoa plant productivity level at the previous year (Kg/tree). The long-term elasticity and the short-term elasticity was calculated based on Gujarati (2010). The formula was expressed as follow:

$$
\begin{gathered}
\mathrm{E}(\mathrm{sr})=\mathrm{dX} / \mathrm{dK} \times \mathrm{K} / \mathrm{X} \\
\mathrm{E}(\mathrm{lr})=\mathrm{E}(\mathrm{sr}) / \delta
\end{gathered}
$$

Where: $\mathrm{E}(\mathrm{sr}) \quad$ : short-term supply elasticity; E(lr) : long-term supply elasticity; $\mathrm{dX} / \mathrm{dK}$ : the value of good offered for the cocoa price; $\mathrm{X}$ : the mean of the dependent variable (the mean of the cocoa plant produced anf the plant productivity level); K: the mean of the independent variable (the cocoa's price).

Yoga et al. (2018) in a study entitled "Supply Response of Paddy in East Java: Policy Implications to Increase Rice Production" was using Cobb-Douglas, Nerlove Partial Adjustment, econometric analysis (stationery test), co-integration test, and Error Correction Model (ECM). The ECM model was employed to estimate the rice paddy supply response in East Java in the short and long-term periods by using some variables in the model. The previous studies were rarely applied to the ECM model to analyze the rice paddy supply response. This model showed that the short and long-term period correlation remains unknown. The supply response on all agricultural commodities were required a time lag. On a short-term period, the pricechanges factor couldn't be responded to by the farmer, especially during the production period. The production period was also required its biologic process. Therefore, the partial Nerlove model utilized to predict the time-lag appeared on the model.

This model was calculated the elasticity of the rice paddy cultivating area $\left(A_{t}^{d}\right)$ by using the real grain price at year of $\mathrm{r}\left(P_{t}\right)$, the real corn price $\left(P_{c t}\right)$, irrigation land area $\mathrm{i}\left(I_{t}\right)$, curah hujan $\left(R_{t}\right)$, the rice paddy cultivating area size at the previous year $\mathrm{r}\left(A_{t-1}^{d}\right)$ and predictor vector $(\beta)$. The partial Nerlove model used in this study were::

$$
\left(A_{t}^{d}\right)=\beta_{0}+\beta_{1} P_{t}+\beta_{2} P_{c t}+\beta_{3} I_{t}+\beta_{4} R_{t}+\beta_{5} A_{t-1}^{d}+\varepsilon_{t}
$$

The partial Nerlove method would be transformed into a Cobb-Douglas linear equation which expressed through as follow:

$$
\operatorname{Ln} A_{t}^{d}=\operatorname{Ln} \beta_{o}+\beta_{1} \operatorname{Ln} P_{t}+\beta_{2} L n P_{e t}+\beta_{3} L n I_{t}+\beta_{4} L n R_{t}+\beta_{5} \operatorname{Ln} A_{t-1}^{d}+\varepsilon_{t}
$$

Based on the Cobb-Douglas model, the short-term elasticity for the each independent variable could be seen by the regression coefficient of the each variable. The regression coefficient variable in this model was examined using the t-test to determined the significancy level on the variable used (Denziana, et.al., 2014). The long-term elasticity could be determined using the following formula:

Long-Term Elasticity $=$ Short-Term Elasticity $/\left(1-\beta_{5}\right)_{t}$

The anaysis using the time-series data usually required a stationary testAnalisis menggunaka to assure the validity process. The stationery test in this study done by using the Augmented Dickey Fuller (ADF) test. This test done by adding the augmentation to the equation and adding a value that could be influenced 
the time interval fo the $\Delta \mathrm{Yt}$ variable (Gujarati, 2004). ADF Test done by predicting the following equation:

$$
\Delta Y_{t}=\beta_{1}+\beta_{2}+\delta Y_{t-1}+\sum_{i=1}^{m} \alpha_{1} \Delta Y_{t-1}+\varepsilon_{t}
$$

Where $\varepsilon_{-} \mathrm{t}$ was "white noise" error, where $\Delta Y_{t-1}=\left(Y_{t-1},\left(Y_{t-2}\right), \Delta Y_{t-2}=Y_{t-2}, Y_{t-3}\right.$ etc. The differences of lag determined using a empiric method to prevent the serial correlation error. The Augmented Dickey Fuller (ADF) was getting tested if the $\delta=0$ and the test (ADF) was done by following the asimptotic distribution which was same as the DF statistic, therefore the same critical value could be used. To take the appropriate decision, the comparison between the ADF value that was calculated by the MacKinnon critical value required for the determination of the refusal hypothesis on the root unit. If the statistic of $\delta(\mathrm{ADF})$ computated was not relatively negative (located on the right side of MacKinnon critical-value) on the critical value, the nonstationery $\mathrm{HO}$ didn't refuse. If the HO refused, the the time data series was in stationery state, and no root unit existed (Dziwornu et al. 2013).

The Error Correction Model (ECM) and co-integration test also conducted in this study. ECM was a time-series data that commonly used in a variable with a dependency trait. The ECM method also utilized to create a balanced situation on the correlation between the short-term economic variable and the long-term economic balance (Muhammad, 2014). While, the co-integration test aimed to know the correlation or balance on the independent and dependent variable in a long-term period (Akbar et al., 2016). The co-integration test done by using the Johansen cointegration test (comparing the track statistic and maximum eigen-value). A joint integration on the model used existed if the test showed that the track statistic and the maximum eigen-value were higher than 5\% (Atmaja et al., 2015). But, it also could show that there was an imbalance between the variables, therefore an EMC test must be done to analyze this situation. The model used on the ECM test was as follow:

$$
\Delta A_{t}^{d}=\beta_{0}+\beta_{1} \Delta P_{t}+\beta_{2} \Delta P_{c t}+\beta_{3} \Delta I_{t}+\beta_{4} \Delta R_{t}+\gamma e_{t-1}+v_{t}
$$

The symbol of $\Delta$ used for different variable, where $\Delta A_{t}^{d}$ was the difference of rice paddy cultivating area, $\Delta P_{t}$ was the difference of real grain price at the year of $\mathrm{t}, \Delta P_{c t}$ was the difference of real corn price, $\Delta I_{t}$ was the difference of irrigation area; ; $\Delta R_{t}$ was the differentiated rainfall. While, et-1 was the residual error on the equation or the long-term on the period of $\mathrm{t}-1$ and $v_{t}$ was the error on the short-term period. The $\gamma$ coefficient on the equation also known as the adjustment variable which represented the residual or error (e) on the previous period to correct the change of dependent variable toward the balance manner on the following period. The $\gamma$ coefficient must be significant and has a negative value in step.

Bachtiar et al. (2014) in a study entitled "Supply Response and Corn Price Volatility in Indonesia" was using a GARCH model. The supply response equation was estimated by the price GARCH equation. The supply response equation provided suggestions to the agribusiness run in the agricultural field. This study was focusing on the corn commodity price volatility model in Indonesia by utilizing some GARCH type approach model. The empirical specification from the corn supply response model was described as follow:

$$
\begin{aligned}
L N Q_{t}=b_{0} & +b_{1} L N Q_{t-1}+b_{2} L N F U P_{t}+b_{3} L N P A_{t}+b_{4} L N P P C_{t}^{e}+b_{5} L N P P R_{t}+b_{6} L N R P C \\
& +b_{7} L N h_{t}+\varepsilon_{t}
\end{aligned}
$$

Where: $L N Q_{t}=$ the corn commodity volume production at the period of $\mathrm{t}$; $\left.L N Q_{t-1}\right)=$ the corn commodity volume production at the period of $\mathrm{t}-1 ; L N F U P_{t}=$ the fertilizer price on the period of $\mathrm{t}$; $L N P A_{t}=$ the corn commodity cultivating area on the period of $\mathrm{t}$; $L N P P C_{t}^{e}=$ the real corn commodity price on the producer level in the period 
of $\mathrm{t} ; L N P P R_{t}=$ the real rice paddy on the producer level; $L N R P C=$ the real corn commodity on the wholesaler level on the period of $t ; L N h_{t}=$ harga varian yang diharapkan pada waktu t; $\varepsilon_{t}=$ stochastic error in the discrit period and $\Omega_{t-1}$ was the summarize of information from the past status until the periof of $t-1$. The price spesification equation was expressed as follow:

$$
\mathrm{LNPPC}_{t}^{e}=d_{0}+d_{1} L N P P C_{t-1}+d_{2} L N P P C_{t-2}+\varepsilon_{t}
$$

Where: $\mathrm{LNPPC}_{t}^{e}=$ the corn commodity on the producer level expected in the period of $t ; L N P P C_{t-1}=$ the real corn commodity price on the producer level in the period of $\mathrm{t}-1 ; L N P P C_{t-2}=$ the real corn commodity price on the producer level in the period of $\mathrm{t}-2 ; \varepsilon_{t}=$ stochastic error in the discrit period and $\Omega_{-}(\mathrm{t}-1)$ was the summarize of information from the past status until the periof of $t-1$. The variance expected from the corn commodity price on the producer level $\left(h_{t}\right)$ was obtained from the variance equation which expressed as:

$$
L N h_{t}=b_{1}+b_{2} \varepsilon_{2 t-1}^{2}+b_{3} h_{t-1}
$$

All type of the GARCH alternative model were tested (GARCH (1.2), GARCH (2.1), and GARCH (2.2)). The Akaike and Schawrz criteria used to show the best model applied in this study.

Nugroho et al. (2015) in the study entitled "Salacca zalacca Supply Response in Salatiga City" was using a descriptive method with multiple linear regression techniques as its analysis tool. The model used was the Partial Adjustment Nerlove Model combined with the direct approach to the plant volume production. The factors affected the supply response was analyzed using the multiple partial Nerlove Model in the form of the natural algorithm $(\mathrm{Ln})$ as expressed below:

LnQt $=$ Lna + a1LnPt-1 + a2LnAt + a3LnWt + a4LnQt-1 + a5 LnQrt-1 + a6 LnPzt +

$$
\text { e. }
$$

Where: LnQt was the Salacca zalacca supply response in Salatiga City; LnPt-1 was the Salacca zalacca commodity at the previous year; LnAt Salacca zalacca plant that contributed to the volume production at the previous year; LnWt was the rainfall average during the cultivating years; LnQt-1 was the Salacca zalacca plant that contributed to the volume production at the previous year; LnQrt-1 was the rambutan volume production at the previous year; and LnPzt was urea fertilizer during the year of cultivation. The supply elasticity could be seen by the short and long-term elasticity with the calculation formula of the short-term elasticity expressed as follow:

$$
\operatorname{Epd}=b_{i} \frac{\bar{X}}{\bar{Y}}
$$

Where: Epd was the short-term price elasticity; Bi was the independent variable regression coefficient; $\mathrm{X}^{-}$was the mean value of the $\mathrm{i}$ independent variable; $\mathrm{Y}^{-}$the mean value of the i dependent variable. While the long-term elasticity was formulated as :

$$
\operatorname{Epj}=\frac{E P D}{\delta}
$$

Where: Epj was the long-term elasticity; Epd was the short-term elasticity; $\delta$ was the adjustment coefficient $(0<\delta<1)$. This study was employed the multiple linear regression in a model transformed in the form of the natural algorithm (Ln). The multiple regression model in the form of Ln was a multiple algorithm model that used the regression coefficient value as its elasticity value. Therefore, the elasticity value was the regression coefficient from each variable.

Magfiroh et al. (2018) in the study entitled "Corn Commodity Supply Response in Indonesia" was using the ECM model. There were some procedures used to study the supply response: 1) stationery test or root test, used to avoid the fake regression, 2) determination of the optimum lag, done by using the information criteria (the 
lowest Akaike Information Criterion/AIC and Schwarz Bayesian Criterion/SBC value from the lag recommended, 3) Johansen Cointegration Test, determined the stationery state of a variable, and 4) Error Correction Model (ECM) combined the long-term and short-term effect. This model also explained all the variables used.

The red thread from those studies explained as the use of partial adjustment model and expectation model (Nerlove Model) as the most common model in analyzing the supply response on the agricultural commodity. Other forms of the model such as Cobb Douglas, ECM, GARCH, and the cointegration model also could be used in analyzing the supply response. The type of model used could be varied depends on the aim of the study

\section{CONCLUSION}

Most studies identified that the agricultural commodity supply response was finally generated by the farmer's supply response sensitivity. If the farmers have a dominant supply response on certain factors, these factors would be identified easily by the stakeholders in improving the production. There were many factors affected the supply response, but most studies found that production volume, export, and import majorly contributed to the supply response. The common problem-solving method used was the Partial Adjustment Model and Adaptive Expectation Model Nerlove Model

\section{RECOMMENDATION}

Studies assessing the potential of the Indonesia agricultural commodity is required to be conducted in the future. The result from these studies would be beneficial for the government in taking future strategic policies in maintaining the national economic stability, especially on the unpredictable situation (such as the global outbreak).

\section{REFERENCES}

Abidin, M. Z. (2015). Dampak Kebijakan Impor Beras Dan Ketahanan Pangan Dalam Perspektif Kesejahteraan Sosial. Sosio Informa, 1(03), 213-230. Retrieved from https://media.neliti.com/media/publications/52839-ID-dampakkebijakan-impor-beras-dan-ketahan.pdf

Akbar, R. A., Rusgiyono, A., \& Tarno. (2016). Analisis integrasi pasar bawang merah menggunakan metode Vector Error Correction Model (VECM) (Studi kasus: Harga bawang merah di Provinsi Jawa Tengah). Jurnal Gaussian, 5(4), 811820.

Atmaja, M. A. J., Kencana, I. P. E. N., \& Gandhiadi, G. K. (2015). Analisis kointegrasi jumlah wisatawan, inflasi dan nilai tukar terhadap Produk Domestik Regional Bruto ( PDRB ) Povinsi Bali. E-Jurnal Matematika, 4(3), 83-89.

Anindita, R. 2008. Pendekatan Ekonomi untuk Analisis Harga. Jakarta: Kencana Prenada Media Group.

Anwar, A., 1986. "Masalah dan Kebijaksanan Pangan di Indonesia." Disampaikan pada Penataran Analisis dan Keterpaduan Sektoral dan Regional Perencanaan Pertanian, 15 September-22 Nopember 1986. Bogor. 
Ayinde, O. E., Bessler, D. A., \& Oni, F. E. (2017). Analysis Of Supply Response And Price Risk On Rice Production In Nigeria. Journal of Agribusiness and Rural Development, 43(1), 17-24. https://doi.org/http://dx.doi.org/10.17306/J.JARD.2017.00279

Bachtiar, R. R., Chang, W.-I., Anindita, R., \& Mustadjab, M. (2014). Supply Response and Corn Price Volatility in Indonesia. Greener Journal of Business and Management Studies, 4(3), https://doi.org/10.15580/gjbms.2014.3.060314262

058-069.

Berhman J. R, 1968, Supply respone in underdeveloped agriculture; A case sudy of major annual crops in Thailand, 1937-1963. North-Holland Publishing Company. Amsterdam. pp:151-184.

Cagan, P. 1954. "The Monetary Dynamics of HiperInflations". In. M. Frieman (Ed). Studies in the Quantity Theory of Money. University of Chicago Press. Chicago, hlm.. 25-177.

Cahyono, G.W.P., Anindita, R., Nugroho, C. P. (2020). Analysis Of Cocoa Supply Response In Indonesia. Agricultural Socio-Economics Journal, XX(1), 79-88. http://dx.doi.org/ 10.21776/ub.agrise.2020.020.1.10

Denziana, A., Indrayenti, \& Fatah, F. (2014). Corporate financial performance effects of macro economic factors against stock return. British Journal of Psychiatry, 5(2), 17-40. https://doi.org/10.1192/bjp.205.1.76a.

Dziwornu, R. K., \& Vitor, D. A. (2013). Stock exchange performance and economic growth in Ghana : Is there a causal link? Asian Journal of Empirical Research, 3(9), 1152-1165.

Dellal, I., \& Koç, A. A. (2003). An Econometric Analysis of Apricot Supply and Export Demand in Turkey. Turkish Journal of Agriculture and Forestry, 27(5), 313321.

Edison, \& Siata, R. (2018). Analisis Respon Penawaran Komoditi Jagung Di Kabupaten Muaro Jambi. Journal of Agribusiness and Local Wisdom, 1(1), 68-76.

Ferjani, A., \& Zimmermann, A. (2013). Estimating Agricultural Supply Response with the dynamic sectormodel SILAS-dyn. Journal of Socio-Economics in Agriculture (Until 2015: Yearbook of Socioeconomics in Agriculture), 6(1), 155-176. $\quad$ Retrieved

from https://ideas.repec.org/a/cha/ysa001/v6y2013i1p155-

176.html\%OAhttp://files/704/Ferjani และ Zimmermann - 2013 - Estimating Agricultural Supply Response with the d.pdf\%0Ahttp:/ / files /705/v6y2013i1p155-176.html

Firdaus, M. (2014). Analisis Faktor-Faktor Respon Penawaran Kacang Kedelai Di Indonesia. 42-48.

Fitri, A. (2018). Pengaruh Pengurangan Impor Beras Pakistan Terhadap Petani Beras Indonesia. JOM FISIP, 5(1), 1-15.

French, B. C., \& Matthews, J. L. (1971). A Supply Response Model for Perennial 
Crops. American Journal of Agricultural Economics, 53(3), 478.

Griffin, R. W., \& Pustay, M. W. 2015. Bisnis Internasional: Sebuah Perspektif Manajerial. Salemba Empat. Jakarta.

Gujarati, Damodar N. Dawn C. Porter. (2010). Basic Econometrica. Fifth Edition. New York : Mc Graw Hill.

Gujarati, D. N. (2004). Basic Econometrics (4th ed.). New York: The McGraw-Hill Companies.

Gujarati, D., 1989. Basic Econometrics. Second Edition. Mc.GrawHill. NewYork.

Heriyanto, Anindita, R., \& Lestari, R. Y. (2013). Dinamika Respon Penawaran Komoditas Kacang Tanah di Indonesia. Prosiding Seminar Hasil Penelitian Tanaman Aneka Kacang Dan Umbi, 422-430. Retrieved from http:/ / pse.litbang.pertanian.go.id/ind/pdffiles/ART4-1a.pdf

Heriyanto, \& Krisdiana, R. (2011). Model Respon Penawaran Komoditas Ubikayu. Majalah Ekonomi, (3), 230-237.

Hermawan, I., \& Adam, L. (2010). Analisis Faktor-Faktor yang Mempengaruhi Penawaran Dan Permintaan Serat Kapas di Indonesia. Jurnal Ekonomi \& Kebijakan Publik, 1(1), 101-128. https://doi.org/10.22212/JEKP.V1I1.77

Hernawaty P, M., Abdurrahman, \& Yanti, N. D. (2016). Respon Penawaran Padi Di Kalimantan Selatan. Prosiding Seminar Nasional Lahan Basah Tahun, 1, 420425.

Houck, P dan Ryan, J. 2003 Weather Risk and The Off-Farm Labor Supply of Agricultural Households in India. Paper in International Association of Agricultural Economists Conference, Gold Coast. Australia. Pp. 1-15.

Intriligator, M. D. 1980. Econometric Models, Techniques and Applications. PrenticeHall of India Private Limited. New Delhi, hlm. 78-149.

Juliandi, Azuar, Irfan, Saprinal Manurung. 2014. Metode Penelitian Bisnis Konsep dan Aplikasi. USU Press. Medan.

Judge. 2004. Fndamental of Econometrics: Theory and Applications. University of Wisconsin Press. U.S.A.

Johansen, S. (1988). Statistical analysis of cointegration vec $\neg$ tors. J. Econ. Dyn. Cont., 12, 231-254.

Johansen, S. (1995). A statistical analysis of cointegration for I(2) variables. Econ. Theory, 11(1), 25-59.

Khan, S. U., Faisal, M. A., U1 Haq, Z., Fahad, S., Ali, G., Khan, A. A., \& Khan, I. (2019). Supply response of rice using time series data: Lessons from Khyber Pakhtunkhwa Province, Pakistan. Journal of the Saudi Society of Agricultural Sciences, 18(4), 458-461. https://doi.org/10.1016/j.jssas.2018.03.001

Koutsoyiannis, A., 1977. Theory of Econometrics. The Macmillan Press Ltd, USA. 
Kmenta, J. 1971. Elements of econometrics. Macmillan Pub. Co., Inc. New York, hlm.347-405.

Lau, L.J. dan Yotopoulus, P.A. 1972. Profit, Supply, and Factor Demand Functions. American

Journal of Agricultural Economics,. 54:11-18.

Magfiroh, I. S., Zainuddin, A., \& Setyawati, I. K. (2018). Respon Penawaran Jagung di Indonesia. Buletin Ilmiah Litbang Perdagangan, 12(1), 47-72. https://doi.org/10.30908/bilp.v12i1.309

Magrini, E., Balié, J., \& Morales Opazo, C. (2016). Price signals and supply responses for staple food crops in SSA countries (No. 1601). Retrieved from http:/ / hdl.handle.net/10419/126553

Mahmudah, Rinawati. 2014. Analisis Respon Penawaran Kacang Hijau (Phiseolus radiatus) Di Indonesia. Skripsi. Universitas Brawijaya. Malang.

McKay, A., Morrissey, O., \& Vaillant, C. (1998). Aggregate export and food crop supply response in Tanzania. CREDIT Research Paper, 4(98/4), 1-22.

Muhammad, M. (2014). Kointegrasi dan estimasi ecm pada data time series. Jurnal Konvergensi, 4(1), 41-51.

Nerlove, M. 1956. "Estimates of the Elasticities of Supply of Selected Agricultural Commodities." Journal of Farm Economics. 38: hlm.496-509.

Nerlove, M. 1958. "Distributed and Estimation of Long Run Supply and Demand Elasticities: Theoritical Consideration". Journal of Farm Economics. 9: hlm.301-311.

Nugroho, A., Rahayu, E. S., \& Ani, S. W. (2015). Respon Penawaran Salak ( Salacca Zalacca) Di Kota Salatiga. AGRISTA, 3(2), 25-35.

Oktavia, H. F. (2019). Respon Penawaran Jagung (Zea Mays) Di Kabupaten Malang, Jawa Timur Henita. Journal of Chemical Information and Modeling, 53(9), 1689-1699. https://doi.org/10.1017/CBO9781107415324.004

Prasada, I.M.Y., Dhamira, A., Nugroho, A.D. (2018). Supply Response of Paddy in East Java: Policy Implications to Increase Rice Production. AGRARIS: Journal of Agribusiness and Rural Development Research, 4(2), 129-138. http://dx.doi.org/10.18196/agr.4268

Quiggin, John. 1991. Contradictory Predictions On Supply Response Under Stabilization: A Reconcialiation. Australian Journal of Agricultural Economics, Vol. 35(3). Pp:285-294.

Simanjuntak, P. T. H., Arifin, Z., \& Mawardi, M. K. (2017). Pengaruh Produksi, Harga Internasional Dan Nilai Tukar Rupiah Terhadap Volume Ekspor Rumput Laut Indonesia (Studi pada tahun 2009 - 2014). Journal of Business Administration, 50(3), 163-171. Retrieved from administrasibisnis.studentjournal.ub.ac.id

Sugiarto, Tedy Herlambang, Brastoro, Rachmat Sudjana, Said Kelana. 2005. 
Ekonomi Mikro: Sebuah Kajian Komprehensif. PT Gramedia Pustaka Utama. Jakarta

Sulaiman, S., Kushendrayana. 2013. Pengantar Statistika: Aplikasinya dalam Bidang Pariwisata,Usaha Perjalanan dan Perhotelan. Alfabetha. Bandung.

Sulistyo, A., Syafrial, \& Anindita, R. (2017). Analisis Respon Penawaran Padi Indonesia. Jurnal Agribest, $1(2), \quad 38-44$. https://doi.org/10.32528/agribest.v1i1.1249

Tomek W, \& Robinson KL. (1990). Agricultural Product Prices. London: Cornell University Press.

Tupamahu, Y. M. (2017). Respon penawaran kacang tanah di indonesia. Jurnal Ilmiah Agribisnis Dan Perikanan (Agrikan UMMU-Ternate), 10(2), 56-64.

Wahyu Priyo Cahyono, G., Anindita, R., \& Puspo Nugroho, C. (2020). Analysis of Cocoa Supply Response in Indonesia. Agricultural Socio-Economic Journal, 20(1), 79-86. https://doi.org/10.21776/ub.agrise.2020.20.1.10

Yoga Prasada, I. M., Dhamira, A., \& Dwi Nugroho, A. (2018). Supply Response of Paddy in East Java: Policy Implications to Increase Rice Production. AGRARIS: Journal of Agribusiness and Rural Development Research, 4(2), 130-138. https://doi.org/10.18196/agr.4268

Yotopoulos, P.A. and J.B. Nugent, 1976. Economics of Development. Empirical Investigations. Harper International Edition. Harper and Row Publishers. New York.

Zakariya, M. L., Musadieq, M. Al, \& Sulasmiyati, S. (2016). Pengaruh Produksi , Harga , dan Nilai Tukar terhadap Volume Ekspor ( Studi pada Volume Ekspor Biji Kakao Indonesia Periode Januari 2010-Desember 2015 ). Jurnal Administrasi Bisnis, 40(2), 139-145. Retrieved from administrasibisnis.studentjournal.ub.ac.id 